\title{
The Legal Geography of Expansion: Continental Space, Public Spheres, and Federalism in Australia and Canada
}

\section{ROBERT STACK*}

This article is a comparative, historical overview of Canadian and Australian federalism. The author seeks to answer three questions: Why did the founders of each country choose a federal system? What sort of federation did they want? What sort of federation did the countries have after judicial review?

The first part of the article argues that the rise of federalism was related to nineteenth-century trends such as industrialization and the increasing importance of continental as opposed to the coastal territories. The nation-builders required, the author asserts, a constitutional apparatus that could reconcile economic and nationalist motives for expansion with sentiments of historic colonial attachment and local autonomy. A federal division of sovereignty was therefore attractive.

The second part of the article examines what the framers specifically wanted from their federations and suggests reasons why these expectations were partially satisfied and partially disappointed. According to the author, the division of legal space permitted national expansion while maintaining regional autonomy. However, federalism offered protection and autonomy not just to levels of government, but to the "private" and "public" spheres of federal society. These spheres were dynamic rather than stable.

Finally, in the third section on judicial review, the author argues that centralization in both countries was linked to the "expansion of public space" and the rise of interventionist economics and policies. In Canada, however, constitutional protection for the "private" civil law tradition of Lower Canada limited both centralization and federal intervention in the economy.
Cet article se veut un aperçu comparatif et historique du fédéralisme canadien et australien. L'auteur cherche à répondre à trois questions : Pour quelle raison est-ce que les fondateurs de chacun de ces pays ont choisi le régime fédéral? Quel genre de fédération voulaient-ils? Quel genre de fédération at-il existé dans ces pays après la révision judiciaire?

La première partie de l'article insiste sur le fait que la montée du fédéralisme était liée aux tendances du dix-neuvième siècle telles que l'industrialisation et une plus grande importance accordée aux territoires intérieurs par opposition aux territoires côtiers. L'auteur invoque le fait que les fondateurs de ces pays cherchaient un appareil constitutionnel pouvant allier les motifs économiques et nationalistes d'expansion aux sentiments d'attachement colonial historique et d'autonomie locale. Par conséquent, la division fédérale de la souveraineté plaisait.

La deuxième partie de l'article examine ce que les fondateurs recherchaient particulièrement dans leurs fédérations et laisse supposer les raisons pour lesquelles ces attentes furent en partie satisfaites et en partie décevantes. Selon l'auteur, la division de l'ouverture juridique rendait l'expansion nationale possible tout en maintenant une autonomie régionale. Cependant, le fédéralisme assurait protection et autonomie non seulement aux divers paliers du gouvernement, mais aussi aux sphères "privées "et "publiques" de la société fédérale. Ces sphères étaient plutôt dynamiques que stables.

Enfin, dans la troisième section sur la révision judiciaire, l'auteur estime que, dans les deux pays, la centralisation était liée à al'expansion de l'espace public "et la montée des économies et politiques interventionnistes. Au Canada, par ailleurs, la protection constitutionnelle de la tradition du code civil "privé " du Bas-Canada a limité la centralisation et l'intervention fédérale dans l'économie.

\section{TABle OF CONTENTS}

I. INTRODUCTION ........................ 489

II. La Belle ÉPOQUE: A FEderal WORLD . . . . . . . . . . . . . . . . 489

B.A. (Hons.), M.A. (Hist.), (Sask.); LL.B. (Victoria); completing articles at Priel, Stevenson, Hood \& Thornton, Saskatoon, Saskatchewan. The author would like to thank University of Victoria Professor John McLaren, who generously encouraged and judiciously supervised this research. 
III. THRESHOLD OF NATIONS $\ldots \ldots \ldots \ldots \ldots \ldots \ldots \ldots \ldots \ldots$

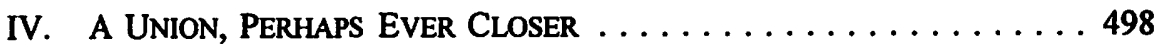

V. Sovereign SPHERES: PUblic AND PRIVATE $\ldots \ldots \ldots \ldots \ldots \ldots 503$

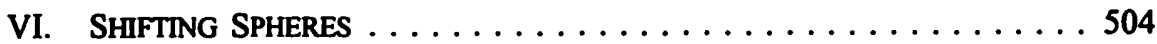

VII. Conclusion $\ldots \ldots \ldots \ldots \ldots \ldots \ldots \ldots \ldots \ldots \ldots \ldots \ldots \ldots \ldots \ldots \ldots$

\section{INTRODUCTION}

This article is a brief, comparative history of federalism in Australia and Canada. The topic is obviously very large, but it is possible to suggest concise answers to a few basic questions: Why did both countries choose union under a federal model? What did the framers of the respective constitutions think of "federalism" in general, and how did they envision the specific division of powers between the central and regional governments? How have courts interpreted the federal aspects of the constitutions? In one sense, this paper is an intellectual history. It presents the story of a legal and political idea federalism - at a specific time in history - the late nineteenth century - and in two specific places - Canada and Australia. Both the unity of time and the remarkable basic similarity of Australian and Canadian history make a comparative portrait natural; the revealing contrasts of national composition and national narrative make comparison interesting and useful.

However, while we are concerned with the history of an idea, there are few pure intellectuals in the pages that follow, but rather people who had authority either to legislate or to judge legislation. This is, then, also a study in law and politics, though of a rather extraordinary kind. The framers of the Canadian and Australian Constitutions had a chance to create a national politics as much as practice it; and the judges had to make law as much as interpret it. More interestingly, both creation and interpretation turned on an idea that was somewhat novel: the division of sovereignty between two levels of government - that is, federalism.

\section{LA Belle Époque: A Federal World}

An ironic tone sounds through much of the recent literature on the history of federation and federalism in Canada and Australia. Irony may be an appropriate mode for the federal story, because, as we shall see, it is a history of odd outcomes and unintended effects. It is also probably true that we have come to look warily upon national histories and nationmaking. Canada and Australia emerged from one of the great periods of nation-building, a period about which many thinkers have become particularly suspicious. Canada united in 1867, Australia in 1901. Deep into this fin de siècle historians have traced many of the ills of western society in the twentieth century: industrial conflict, ideological extremism, and violent nationalism. But it is a mistake to ignore the fundamental productivity of the time. If the term fin de siècle has taken on a dark, ominous meaning in post-1918 historiography, la belle époche still captures the enthusiasm of those decades, particularly the last twenty years before World War I, when electricity turned Paris into the city of 
lights and Australian federation, in the words of South Australian Chief Justice Sir Samuel Way, "had struck the keynote of the coming century."

Canada and Australia, as nations and federations, were very much products of their era. Some people might have been unhappy with the great events of 1867 and 1901; few could have been completely surprised. The two great themes of the nineteenth century, it is often said, were liberalism and nationalism. Both seemed everywhere prevailing in the decade of Canadian Confederation: the United States won a war to free its slaves as well as maintain and centralize its federation; Piedmont realized the old dream of Machiavelli, a united Italy; Prussia completed the organization of German central Europe into a national federation; Imperial Japan gave itself a written, liberal constitution. As well, industrialization, which had slowly transformed the economy of Great Britain, spread to each of these countries, often with extraordinary vigour. Much of what we call the "West," including modern Canada and Australia, dates from the half century 1860-1914.

But what is less often emphasized is the relationship of federalism to these trends and events. Imperial Germany, the Dominion of Canada, and the Commonwealth of Australia all adopted a federal system of government. Both the United States and Switzerland (in the Constitution of 1874) recommitted themselves to the federal principle, and the AustroHungarian Empire pursued a policy of local federalism. In the next century, federalism became the form of government in such leviathan states as India and the USSR. Indeed, federalism seems to have been as pervasive an idea as liberalism and nationalism. Why?

It has often been said that two revolutions, the American-French and the Industrial, shaped the nineteenth century. The idea helps to explain the rise of federalism. For the liberal revolutions suggested that political borders could change, and that they should conform to cultural identities or utilitarian, economic considerations, rather than dynastic ambitions; and the second industrial revolution radically altered the economic geography of the West and its colonies. The original North American and Australian white settlements were the culmination of the gradual shift of power and wealth away from the Mediterranean to the Atlantic coast of Europe. From early modern times, maritime countries with central monarchies, such as Spain, France and then Great Britain, dominated Europe, in part because they spawned colonies along the ocean coasts and riverways of the "new world." Watercourses defined these colonies. In British North America, Nova Scotia was the defensive promontory, Upper Canada the economic peninsula; settlement in New Brunswick and Lower Canada followed rivers and $L a$ Fleuve. Every major city in the new Commonwealth of Australia looked out on the Pacific, and most of them were near a branch of the Murray-Darling River System. As long as such colonies had to hug river valleys or seacoasts, they might remain, in relation to each other, continental islands. However, first wagon-roads and canals, then telegraphs and railroads opened up new possibilities to develop common economic spaces and exploit the vast interior territories of the North American and Australian continents. Technological change and industrialization, which had the effect of shrinking relative distance, offered colonial societies the chance to continue and accelerate their basic experience: the 
expansion, rationalization, and exploitation of space. However, the continuity and consummation of this colonial trend effected a radical change in global history: if the age of oceans had belonged to the maritime monarchies, the age of steel would belong to the continental empires, and these empires were federal.

\section{THRESHOLD OF NATIONS}

If economic and territorial expansion was to continue, however, certain questions, mostly political, needed answering. Who was to build these railroads? To which colony did any interior territories belong? According to what rules would intercolonial trade conduct itself? How could colonial co-operation and organization reconcile themselves with the traditions of colonial independenceand monarchical loyalty? With these questions began the search for a federal arrangement.

The words federal, federation, and federalism derive from the Latin root foedus or covenant, which is related to fides. Thus the word has always suggested a promise, undertaking or pledge; and the notion of a federal code or compact has as much to do with the law of contract, partnership and trust as it does ideas of sovereignty, constitutional authority or international law. ${ }^{2}$ Indeed, William Riker describes federations as "bargains" struck between various parties. What causes people to enter federal bargains? Riker notes two conditions present at the birth of every modern federation: the opportunity to expand territory for economic or military reasons, and some military threat, pressure or purpose. ${ }^{3}$ Technological change and the colonial instinct for expansion, as we have seen, provided the underlying logic of colonial integration. The history of the federal idea, which seems to have been around for many years on both the American and Australian continents, ${ }^{4}$ was to some degree the growing contemporary awareness that further expansion might be beneficial and would require constitutional change. But the realization of union depended upon other factors. An infinite number of contingent realities, personal inclinations, narrow political or economic interests, worked for or against federation. The most important of these shifting circumstances were the ones touching on Riker's requirement of an external threat or military purpose. But perhaps Riker needs to incorporate a third factor into his list: the social or intellectual acceptability of federation based on the recognition of shared values, experiences or purposes. This consideration was important both for the foundation and evolution of Canadian and Australian federalism.

The Chief Justice of Victoria in 1896 wrote that the Australian colonies "were rather in the position of a young man and maiden. Each was anxious to have the other, but neither was anxious to begin." It is probably true that political integration was halting in comparison with the more consistent constricting of economic and social space. For

S.R. Davis, The Federal Principle: A Journey Through Time in Quest of a Meaning (Berkeley: University of Califomia Press, 1978) at 3, 5.

3

J.A. La Nauze, The Making of the Australian Constitution (Melbourne: Melbourne University Press, 1971) at 1; L.F.S. Upton, "The Idea of Confederation: 1754-1858" in W.L. Morton, ed., The Shield of Achilles: Aspects of Canada in the Victorian Age (Toronto: McClelland and Stewart, 1968) 184. Irving, supra note 1 at 7 . 
instance, in 1877 the Australian telegraph network reached Western Australia. It is somewhat illustrative that steamships, the Victoria and the Lucinda, ferried around the framers of the Australian and Canadian Constitutions. But more symbolic still was the fact that Henry Parkes' 1889 Tenterfield address, a spur of the Australian federal project, was train-stop oration. It was the coming of steam power to land that revolutionized social and economic experience in the continental archipelagos of British North America and Australia. The 4,500 kilometres of North American railroad in 1840 had grown to 90,100 by 1870 ; this figure leapt to 161,900 by $1880 .{ }^{6}$ Before Confederation, a spiderweb of iron covered Upper Canada; one line snaked up under the southern edge of the Canadian Shield to Rivière du Loup and another stretched down to the winter port of Portland, Maine. Trains began to run between Sydney and Melbourne in 1883, the same year the Premiers approved a Federal Council for the continent. ${ }^{7}$ The completion of the MelbourneAdelaide (1887) and the Sydney-Brisbane (1889) lines ${ }^{3}$ meant that the southeast corner of the Australian continent, its economic core, had a modern transportation system. Railroads provided visual evidence of the reality which the gradual rise in productivity, incomes, and population also suggested: the dynamism and maturation of colonial societies. The building of the great Victoria train-bridge over the St. Lawrence was emblematic of mid-Victorian steel age values - a mixture of practical science and romantic vision, spirited pluck and plain materialism - that one can also locate in the discussions of national and constitutional architecture.

The bridge was symbolic of something else: the synthesis of the commercial interests of Upper and Lower Canada, and the reality that the Union of the Canadas provided the sort of economy of scale that was a fundamental incentive for federation in Central Europe, North America, and Australia. For this reason, the difficulties of developing a common market in a space governed by independent states were more evident in Australia than Canada. Much like Virginia and Maryland, which squabbled over the Potomac in the years before the Constitutional Convention of 1787, New South Wales, Victoria, and South Australia bickered over the use of the natural inland trade artery, the Murray River, for customs revenue and irrigation. ${ }^{9}$ The eastern colonies built rail-lines to capture each other's trade, and engaged in mutually destructive fare and freight rate cutting. Competition also effected the two main sources of government revenue: tariffs and land sales. Pure mercantilism broke out when Victoria brought in a tariff intended to be protective. ${ }^{10}$ This economic balkanization occurred in 1873, two years after the old customs union of Central Europe had become a national federation. For good reason, James Service, once a premier of Victoria, declared that the sources of government finance represented " $a$ lion in the path of federation"; he implored the Melbourne

P. Waite, Years of Struggle 1867-1896 (Toronto: Grolier, 1985) at 17. Irving, supra note 1 at 3.

R. Norris, "Towards a Federal Union" in B.W. Hodgins, D. Wright \& W.H. Heick, eds., Federalism in Canada and Australia: the Early Years (Waterloo: Wilfred Laurier University Press, 1978) 173. For a discussion on the role of the Murray River in the history of Australian federalism, see G.D. Patterson, "The Murray River Border Customs Dispute, 1853-1880" (1962) 2 Business Archives and History; D. Wright "The River Murray: Microcosm of Australian Federal History" in B.W. Hodgins, D. Wright \& W.H. Heick, eds., Federalism in Canada and Australia: the Early Years (Waterloo: Wilfred Laurier University Press, 1978) 277.

Norris, supra note 8 at 174 . 
Conference of 1890 to kill it, for otherwise it would kill the federal project. "In short, colonial borders took on an artificial character as Australia integrated economically, and their removal was likely the prime motive for union.

In British North America, the issue of tariffs also came up during the debates on federalism. Like many in Australia, George Brown, the Reformer from Upper Canada, complained about customs posts arresting traffic between Canada and the Maritime Colonies. Union with the Maritimes would also secure for Canada a winter port. ${ }^{12}$ But federation, especially for men like Brown, involved something larger than a customs union with the Atlantic provinces. The enticing vision was a vast common market, stretching from one ocean to another, organized under a federal government with enough weight to draw a tide of investment capital for the augmentation of infrastructure, particularly in the undeveloped west. ${ }^{13}$ If Australians were pushed toward federation by the harmful effects of continental, intercolonial competition, Canadians were drawn to it by the opportunities for continental expansion. The Fathers of Confederation were aware that they were seeking to achieve by peaceful means what was often accomplished violently. During the parliamentary debate on Confederation, Brown declared:

I go heartily for the union, because it will throw down the barriers of trade and give us the control of a market of four millions of people.... All over the world we find nations eagerly longing to extend their domains, spending large sums and waging protracted wars to possess themselves of more territory, untilled and uninhabited.... But here, (Mr. Speaker), is a proposal which is to add, in one day, near a million of souls to our population - to add valuable territories to our domain, and secure to us all the advantages of a large and profitable commerce. ${ }^{14}$

The goal was imperial but the means were consensual.

Here we see an important point about federalism in Canada, Australia, and elsewhere: federalism is attractive to parties who wish to expand but are either unable or unwilling to compel submission, perhaps because they feel some kinship with the people on the coveted territory. Some fratricidal violence had recently been used to unify Italy and Germany, but Germans never would have accepted a full Prussian war of conquest. As new liberal ideas offered nations a way to change governments without violence, federalism offered the possibility of altering borders peaceably.

However, it is natural for a federal movement, as a form of nationalism, collective pride or identification, to view the world according to its values and loyalties. Thus, while no colony in the Australian Continent or British North America seriously contemplated attacking its neighbours, the attitude toward the indigenous population was something different, as was the Canadian perspective of the Northwest. Historians regularly state that

Service actually said "lion in the way" but the more eloquent phrase has become the famous one. La Nauze, supra note 4 at 11. and Stewart, 1963) at 20 [hereinafter Confederation Debates].

Ibid. at 68.

Ibid. 
Upper Canada saw the West as a potential colony. That is a little too simplistic. An important reason for federation was the establishment of a body that could deal with the organization and development of Rupert's Land, a task beyond the capacities of both the colonies and the Imperial Government. ${ }^{15}$ But, in the vital respect of authority and integration into Confederation, Canada did not so much formulate a program toward the region as toward different groups in it. Native policy was frankly imperialistic; the white settlers eventually invoked a sort of paternal federalism, which led to the creation of Alberta and Saskatchewan. But central Canada was divided and uncertain on whether the Metis were within the circle of the new federal community, where each side disarms and agrees to the consensual principle. Inconstancy on this point helps explain the different results of the Northwest crises of 1869 and 1885.

One could certainly argue that the war against the Metis fulfils Riker's requirement of a specific military purpose for federation, but it is perhaps more accurate to say that the Fathers of Confederation saw the Northwest as a space that needed aggressive policing, not conquest. In any case, the course of the American Civil War was no doubt a cause of Confederation. Americans had invaded Canada before, their relations with Britain were ticklish and uncertain, and by 1862 British North America had to recognize that it was soon likely to share the continent with a victorious army, the world's largest. ${ }^{16}$ Whether the United States constituted an actual threat to British North America, and whether Canadian federation constituted a strategic improvement were both debated in the $1860 \mathrm{~s}^{17}$ Whatever the correct answers to these questions were, the advocates of union seem to have had a sincere sense that it would be servile and dangerous for British North America not to do more to protect itself. ${ }^{18}$ But, along with the specific assessments of risk, there was a vague, perhaps more profound fear that the United States represented a general threat to life in British North America: the colonies must come together or they would, as if by the natural force of gravity, slip or sink, be pushed or drawn into the United States. ${ }^{19}$

Another sort of threat disturbed British North America, a menace not so much to security as social peace: political impasse in the Union of the Canadas. Canada, as noted above, provided the economy of scale that many countries sought to create by a consensus on federalism, but the Union itself had been one of the more imperious of imperial acts in the history of British North America. If it was, in general, difficult to harmonize French and English interests, it came to appear impossible to reconcile Upper Canada's desire for Representation by Population with Lower Canada's commitment to sectional

Ibid. at 56.

16 W.L. Morton, The Critical Years: The Union of British North America (Toronto: McClelland and Stewart, 1964) at 100.

17 G. Martin, "The Case Against Canadian Confederation 1864-1867" in G. Martin, ed., The Causes of Canadian Confederation (Fredericton: Acadiensis Press, 1990) 19 at 36.

18 Confederation Debates, supra note 12 at 72.

19 G.P. Browne, ed., Documents on the Confederation of British North America (Toronto: McClelland and Stewart, 1969) at 127-28 [hereinafter Documents on the Confederation]; Confederation Debates, supra note 12 at $20,50,72$. 
representation. ${ }^{20}$ The federal idea did not solve the problem of balancing regional protection with popular government; but it made resolution easier. In a real sense, Upper and Lower Canada sought federation because only in a wider union could they release the grip they had on each other. Similar reasoning has motivated the push of France and Germany for European Union. Thus the second branch of Riker's test might be met by jurisdictions which seek a larger state to ensure the peace between themselves.

Certainly, though, Canadian Confederation was not the result of a military threat in the same way as the American or even German federations. Defence probably meant even less in Australia. It is true that a highly critical imperial study of Australian defences prompted the seminal federal discussions of the early 1890s. In 1889 Major General Bevan Edwards, an imperial officer, concluded that the colonies of Australia could not properly defend themselves and he suggested a "federation of forces." Henry Parkes, Premier of New South Wales and long an advocate of federation, used the report to call together a colonial conference, which in turn led to the Constitutional Convention of 1891. However, there is more than a little evidence of collusion between Mr. Parkes and Major General Edwards. ${ }^{21}$ Edwards apparently intended to have the Chinese gunboat through Australian waters, just to give federalism some encouragement. ${ }^{22}$ The more or less chimerical concerns about defence were not substantial enough to sustain the federal movement, and, although the 1891 Convention resulted in a genuine blueprint Constitution, the colonial parliaments did not act on it. Federalism was largely dormant until 1897.

On the whole, historian Ronald Norris concludes, no one was particularly worried about defence in the 1890s, and the same, he adds, was true of immigration. New South Welshmen and Victorians may have distinguished between themselves and the rest of Asia, as Canadian whites distinguished between "federated Canadians" and natives or the Metis; but the documents and debates on federation do not indicate a high concern with immigration. ${ }^{23}$ Indeed, authority over immigration was to fall into the list of concurrent jurisdictions. Certainly, the control of borders was an important state power in the new world of fast transoceanic trade and population movement, ${ }^{24}$ but it would be an exaggeration to say that the purpose of federation was an effective White Australia policy.

Immigration and defence were related to the general issue of identity. Does federation presuppose an identity? Is it meant to create one? As noted above, a federal government, like a unitary one, has to distinguish between people: established federations discriminate among citizens, residents and aliens, and nascent federations may differentiate between those who are within and without the new consensual community. In fact, discussions on colonial federalism began when colonists realized that at some point the imperial methods of expansion would no longer be legitimate because New World space was filling with people whose rights appeared to one another as legitimate in a way that indigenous claims

Documents on the Confederation, ibid. at 5, 15,20; Confederation Debates, supra note 12 at 22, 59, 63.

La Nauze, supra note 4 at 8.

Norris, supra note 8 at 184 .

Ibid. at 187.

Irving, supra note 1 at 81 . 
had not. Enough ties bound the British North American and Australian colonies that intercolonial violence was taboo (the same was less true in the South African settlements), but the social or cultural acceptability or attraction of union was a different matter.

Of course, the English-speaking population of both continents shared much: language, culture, and a common colonial experience; loyalty to the mother country, the empire, and the Queen; venerable legal and political traditions, which had, the consensus was, perfected themselves in the idea of responsible government. Many French Canadians were capable of considerable enthusiasm for these political institutions; ${ }^{25}$ at this height of British prestige, some (George Etienne Cartier and then Wilfred Laurier were the great public exemplars) found space in their sense of self for a British American identity. Therefore, a tension runs through the confederation debates between the cultural and religious obstacles to union and the reality of what Cartier called the "sympathies" of British North America. ${ }^{26}$ French and English shared enough at Confederation, Frank LaSelva argues, ${ }^{27}$ that they were capable of fraternity, which may be the sort of human affection that leads to federal government.

As well, technological innovation had the effect of making the colonists more aware of whatever customs they had in common because it created more collective experiences and shared spaces by reducing relative distance ${ }^{28}$ Helen Irving speculates that "it is an invitingly simple, even elegant, image, that a nation might be defined by the ease with which its members could visit each other in trains or send telegrams."29 The shrinking of space was perhaps of particular importance to the sense of community in Canada and Australia, where the "tyranny of distance" ${ }^{30}$ had oppressed the sense of familiarity one might expect from countries that were, in terms of population, quite small.

In the long term, the contraction of continental space was probably most important in challenging that rival of colonial nationalism, British patriotism, which remained, however, a real force in the late nineteenth century. Indeed, the problem was not that the colonists shared nothing, but that they shared it with too many people. The proponents of Imperial federation had a point: the parts of the English-speaking world were rather indistinct. The American heresy of preferring Tom Paine to Edmund Burke only emphasized the common political culture of the self-governing colonies. Since it was quite easy and natural to feel like an Upper Canadian, a British North American and a Briton ${ }^{31}$ at once, there was never an urge for "national liberation," nor a complete rejection of the federal idea on particularistic or imperial grounds.

R.C. Nelson et al., "Canadian Confederation as a Case Study in Community Formation" in G. Martin, ed., The Causes of Canadian Confederation (Fredericton: Acadiensis Press, 1990) 50 at 80. Confederation Debates, supra note 12 at 50.

S.V. LaSelva, The Moral Foundations of Canadian Federalism (Montreal: McGill-Queen's University Press, 1996) at 23-27.

Norris, supra note 8 at 179.

Irving, supra note 1 at 32 .

For a discussion on the role of distance and low population density in the national histories of these continental countries, see G. Blainey, The Tyranmy of Distance: How Distance Shaped Australia's History (New York: St. Martin's Press, 1968).

"Similarly, Australian identity at this time was, Norris argues, tripartite: Norris, supra note 8 at 181. 
Nova Scotia's Joseph Howe was referring to the wider colonial identity when he graciously greeted visitors from Canada: "I am not one of those who thank God that I am a Nova Scotian merely, for I am a Canadian as well." 32 Howe came to regret those words during the confederation debates, where he ranged himself with the critics, but they highlight an interesting fact. No one could deny that Howe was a Nova Scotian, and he likely thought himself a Briton, but he could not easily deny that he was a Canadian in the sense of being a British North American. Identity was not really at question; the debates about union were not so much about identity, or even political borders, but rather horizons, zeitgeists, and personal inclinations. On the one hand were the colonists and colonizers, the Victorian nation-builders and the fin de siècle industrialists; on the other hand, were the settlers, the parish pump politicians, and the rate-paying local merchandisers. One of the expansionists, the Upper Canadian John A. Macdonald, noted in a famous 1860 speech that "we were standing on the very threshold of nations"33 and four years later Macdonald's Lower Canadian ally, George Etienne Cartier, urged British North Americans to cross it: "Shall we be content to remain separate - shall we be content to maintain a mere provincial existence, when, by coming together, we could become a great nation?"34 But not everyone was interested in greatness. Howe mischievously poked fun at his own position when he queried: "Why should union not be brought about? Was it because we wish to live and die in our insignificance?"35

Federal union in Australia and Canada was not a mere commercial bargain; a customs or defensive union was, finally, insufficient. As the pomp and circumstance around the historic events indicate, federation was about nationhood and nation-building, though not nationalism. Irving has a point when she describes unification not as the triumph of national enthusiasm but the fin de siècle temper of dynamism and far-sighted risk taking. ${ }^{36}$ However, union, without violence or coercion, was possible because federalism had room for both the expansive and the local spirit. ${ }^{37}$ The contest between the two shaped the drafting and judicial interpretation of the British North America Act ("BNA") and the Constitution Act, 1900.

Christopher Moore notes that the division of powers was the constitutional issue in the discussions on Canadian union, ${ }^{38}$ and at least one politician had a strong sense of why questions of federalism had become central to politics. During the confederation debates in the Canadian Parliament, Cartier provided an image of the origins of centralized countries:

Martin, supra note 17 at 44.

Morton, supra note 16 at 93.

Confederation Debates, supra note 12 at 50.

C. Moore, 1867: How the Fathers Made a Deal (Toronto: McClelland \& Stewart, 1997) at 44. Irving, supra note 1 at 36.

E.H. Jones, "Localism and Federalism in Upper Canada to 1865" in B.W. Hodgins, D. Wright, \& W.H. Heick, ed., Federalism in Canada and Australia: the Early Years (Waterloo: Wilfred Laurier University Press, 1978) 19 at 22, 37-38. 
In ancient times, the manner in which a nation grew up was different from that of the present day. Then the first weak settlement increased into a village, which, by turns, became a town and a city, and the nucleus of a nation. ${ }^{39}$

But rather than nationhood spreading out, it now came together:

It was not so in modem times. Nations were now formed by the agglomeration of communities having kindred interests and sympathies. ${ }^{40}$

He concluded that the natural diversity of this sort of nation-formation rendered levelling nationalism quixotic: "The idea of the unity of the races was utopian - it was impossible." ${ }^{21}$ Here, in short, was a justification of federalism, which purported to make nationhood and diversity possible by dividing sovereignty. But, as Cartier noted, it was a new era; the Fathers of Confederation could really only draw on one federal model, that of the United States, a nation whose republicanism they abhorred and which had just fought a ferocious war on the issue of states' rights. Thus, without much past experience to guide them, first the Canadian and then the Australian framers began the novel task of cutting legal space in two.

\section{A Union, Perhaps Ever Closer}

Historians commonly play on the irony of Canadian and Australian constitutional development: Canada was to have a central federation but wound up decentralized; Australia was to be a loose union and yet somehow turned into a tight one. The broad outline of this portrait is correct, but perhaps the details of the image will fill in if two points are kept in mind.

First, a federal constitution is not nearly so much like a statute as a treaty or a contract. ${ }^{42}$ The meaning of such a document derives from its terms, the intentions of the parties (which might be plural), the understanding that the interpreter brings to the document, as well as from applicable principles of law or theory and the nature of the "deal." For instance, basic equity suggests that both sides should gain something from a federal covenant, just like any other bargain. Similarly, basic federal principle presumes that both levels of government are to enjoy autonomy, for otherwise a constitution is not federal at all.

Second, and more important, the Australian and Canadian federal Constitutions divided legal space into two fields: private and public. Unless one recognizes this bifurcation, both the original settlement in Canada and the eventual course of judicial review in Australia are difficult to understand.

Ibid.

Confederation Debates, supra note 12 at 50.

42 This holds at least for the interpretation of its meaning, not for its cultural or symbolic significance. 
Many of English Canada's best scholars have argued that the Canadian Constitution, as sketched out at the Quebec Conference of 1864, was (or was meant) to create a strong federal government and leave the provinces in the position of administrative agencies; this scheme, so the theory runs, fell victim to the incompetence or prejudice of the Privy Council.$^{43}$ But the ambiguity of the Canadian federal compact is symbolized by the fact that the "centralist" Quebec Conference resolutions on the division of powers were moved, and in part drafted, by Oliver Mowat, who would create the model of the province-right's Premier when he came to power in Ontario. One has to question whether we know what the framers intended.

It is certain that the Quebec Conference rejected the confederalist spirit of the United States Constitution, as well as the American drafting technique that many thought had insulated American states. During the debates on the division of powers, Edward Chandler, a New Brunswick delegate, argued that the Constitution should contain, as in the United States, a single list of federal powers and leave the rest of the legal field to the provinces. ${ }^{44}$ Charles Tupper and Macdonald agreed that such a design would give more to the provinces, but that was precisely the American mistake: a weak central government and a fragmented sense of loyalty had led to civil war. ${ }^{45}$ The Canadian Constitution, Macdonald would later argue, reserved in the Federal Government the "great mass of sovereign legislation" by virtue of both its general power to legislate for the peace, order, and good government of the dominion, and the great designated powers ${ }^{46}$ (eventually captured in s. 91 of the $B N A$ ): defence, trade and commerce, finance, transport and communications, banking, currency, customs and excise. Moreover, the federal government had unfettered rights of disallowance and reservation over provincial legislation.

It is not difficult to find contemporary expressions of support for central strength. The British tradition of undivided sovereignty must have seemed quite attractive in those days; a central leviathan would be preferable to the civil anarchy south of the border. But legislative union was impossible, as the framers recognized, so even Macdonald repeatedly stressed that the union had to be federal and federation involved a balance. ${ }^{47}$ Like everyone else, he stated the Constitution divided subjects into national and local and gave the second field to the provinces. Designated provincial powers in s. 92 included: police, prisons, and the administration of justice; charities, hospitals, education, and municipalities; local works, public land, and direct taxation. Section 92 also referred to jurisdiction over "all matters of a local or private nature" and "property and civil rights." Edward Cardwell, the Colonial Minister, would call these "large powers." 48 New Brunswick's Charles Tilley told the electors that Confederation offered more regional autonomy than Daniel O'Connell had ever sought for the Home-Rule of Ireland, ${ }^{49}$ and

Further discussion of this point will be found at 507-508, below.

Documents on the Confederation, supra note 19 at 122 .

Ibid. at 122-23.

Confederation Debates, supra note 12 at 44-48.

Ibid. at 43-45; Moore, supra note 35 at 120 .

Documents on the Confederation, supra note 19 at 168.

Ibid. at 174. 
that eleven of the last twelve laws passed in New Brunswick would have fallen under the provincial list. ${ }^{\text {so }}$

Similarly, the defenders of Confederation in Lower Canada saw it as a way to obtain complete independence in matters that affected them as French Canadians. Cartier's supposed mouthpiece, La Minerve, denied Macdonald's reasoning about the origins of the American Civil War: it was the tyrannical exercise of central prerogatives that caused the cataclysm..$^{\text {s1 }}$ But that did not mean that La Minerve saw the Quebec Resolutions as creating a federal colossus. The emphasis in the pro-Confederation French press seems to have been on the necessity of a principled application of the two lists. The Courrier de St-Hyacinthe editorialized, "we cannot accept any union other than a federal union based on the well-understood principles of confederations." And the principle was mutual autonomy: "The two levels of government must be both sovereign, each within its jurisdiction as clearly defined by the constitution." 52

Perhaps it was just propaganda, but the proconfederate press in Lower Canada took the federal veto as a means of enforcing the compact on jurisdiction. ${ }^{53}$ In fact, Macdonald had similarly characterized disallowance and reservation at the Quebec Conference. ${ }^{54}$ Otherwise he described it as an appeal from unjust local laws, ${ }^{55}$ which suggested it was a devise for protecting minorities. If Macdonald intended the federal veto to allow him close supervision of local governments, he said little about it, but then eventual provincialists such as Mowat also kept quiet. It is probably true that different groups and individuals agreed to the Constitution in the hope that it would evolve in the manner they desired. Betting against a wide use of the veto power certainly made some sense. An Imperial competence, it was already falling into disuse, being contrary to responsible government. Moore draws an interesting connection between Mowat the constitutional draftsman, and Mowat the accomplished equity lawyer: whatever the black letters seemed to say, Mowat understood that disallowance would be circumscribed by the greater constitutional principles of responsible government and federalist autonomy. ${ }^{56}$

Mowat realized two other things. First, the Constitution, to some degree, would be what the people wanted it to be. The original Confederation was an act of mid-nineteenth century cabinet government, but twentieth-century suffrages would determine to what extent it was politically possible for a government to exercise its "constitutional" power. Given the strength of localism, which had evolved in the fight for responsible government, the federal government grew apprehensive of its own veto authority. Macdonald sounded the death knell of disallowance when he refused to use it to protect Catholic education rights in New Brunswick. Education, he explained, was local and, according to the federal

\footnotetext{
so Moore, supra note 35 at 120.

st A.I. Silver, The French-Canadian Idea of Confederation (Toronto: University of Toronto Press, 1982) at 37.

Ibid. at 36-37.

Ibid. at 44.

Documents on the Confederation, supra note 19 at 117.

Confederation Debates, supra note 12 at 74.

Moore, supra note 35 at 121-23.
} 
bargain, local affairs were provincial affairs. ${ }^{57}$ Wilfred Laurier sealed up the coffin during the Manitoba school debate, when he also declined to protect minority education rights, citing the federalist principle of strict non-interference. ${ }^{58}$

The second thing Mowat understood was that a constitution is what the court says it is. On several occasions, his Ontario won Privy Council appeals on questions of the division of power. It may be Macdonald did not foresee judicial review of the Constitution, or how a severe application of the federal principle of autonomy could affect such competencies as the general power for peace, order, and good government. But before we turn to the subject of judicial review, we should look at the framing of the Australian Constitution.

The Australian Constitution was the product of a series of meetings and conventions, first in 1890-1891 and then 1897-1898. As the Canadian framers in 1864 quite clearly rejected the American model, the Australians plainly disdained the design (though not the details) of the $B N A$. This scorn requires some explanation, given the similarities between the countries. For if Australia was different from most of the world because it was British, and if it was different from Britain because it was colonial, and different from the United States because of the preference for "manly" over licentious liberty - then what separated Australia and Canada? Helen Irving argues that the Australian framers rejected the Canadian pattern in order to distinguish themselves from their brother-state, ${ }^{59}$ and this point raises the issue of the social or cultural uses of a federal constitution. For liberals, the purpose of a constitutional law is justice; for utilitarians, it is efficacy. Conservatives argue that law is the reflection of organic social relations; so logically a constitution should express an authentic, historic nationhood. But perhaps the post-modernists have a point: existence precedes essence, law creates more than conforms to nature, and constitutions compose rather than resonate a national tenor. However, it is just as easy to say that Australians did not want to begin their national life by aping a close relative.

Besides national pride, the framers had other reasons to suspect the $B N A$. A broad consensus in the federation dialogue seems to have been that the $B N A$ took too much away from the provinces. ${ }^{60}$ Noted above was the debate between Chandler, Tupper, and Macdonald about express powers. The principal framers of the Australian Constitution agreed with the assumption of that debate; that is, that one federal list of powers would favour the local governments, which would hold the residual power. Like Chandler, and unlike Macdonald, the Australian framers wanted to emphasize the authority of the former colonies. ${ }^{61}$ George Dibbs, perhaps the best known critic of federation as it was emerging, suggested a union or a very tight federation, which, he thought, could be achieved by two

W.L. Morton, "Confederation, 1870-1896: The end of Macdonaldian constitution and the return to duality" (1966) I J. Can. Stud. 11 at 15.

Ibid. at 20.

Irving, supra note 1 at 64 .

L. Zines, "Judicial Review in Australia and Canada" in B. Hodgins et al., Federalism in Canada and Australia: Historical Perspectives: 1920-1988 (Trent: Frost Centre for Canadian Heritage and Studies, 1989) 104.

Irving, supra note 1 at 52 . 
lists, the Canadian model. ${ }^{62}$ Across the Pacific, minds seem to have met on the point that one list benefits regional government and two lists serve central power.

Indeed, one is struck by the certainty in Australia that the $B N A$ was highly centralist. To some degree, the climate of opinion may have come from the persuasion of an important opinion-maker, Tasmanian Attorney General Andrew Inglis Clark. ${ }^{63} \mathrm{He}$ had deep sympathies for the United States and studied its constitutional history; he even visited the country in $1891 .{ }^{64}$ The Civil War, he told delegates at the 1890 Conference, was caused by the politics of emancipation, not federalism, ${ }^{65}$ a stark contrast to the anxieties of Macdonald about whether the federal centre could hold. His views on the $B N A$ were those of its opponents in British North America; 1867 was "an example of amalgamation rather than Federation. ${ }^{166}$ Similarly, Edmund Barton, a New South Wales politician who carried a great deal of weight in the sentiments of Australian federalists, declared that Canadian federalism would "more and more, day by day, decade by decade, approximate to a unification, wiping out the States altogether."67

But while personality may have been a cause of the popularity of decentralism, other, more fundamental factors were active. The lustre of the British, unitary model was perhaps less blinding when Britain had herself promoted colonial federalism. The Civil War was retreating into more distant memory, and one could easily argue there had been a relationship between federation and economic growth in the United States, Germany, and Canada ${ }^{68}$ As well, the Australian framers had the extra perspective of decades of federation-building, and it seems they were more sophisticated about it. The federal debate had its experts and even its required readings, particularly James Bryce's great The American Commonwealth. ${ }^{69}$ Thus the Australian framers were perhaps quick to see the potential contradictions in the $B N A$ between the federal residuary and reservation powers and the federalist principle of mutual autonomy.

Finally, it may be that men such as Clarke recognized a strong popular attachment to colonial governments. The Australian Continent lacked Canada's linguistic diversity, but it also lacked the centripetal experiment of the Union of the Canadas. What the "people" thought was more consequential, as well, because the idea of democracy was overtaking that of responsible government. Both the Australian constitutional process and the Constitution itself showed the marks of the three decades that separated it from Canadian Confederation: voters elected delegates for the second Convention, they voted directly on the result, and the Swiss element in the Constitution is one of its most distinctive features.

$62 \quad$ Ibid. at 52.

$63 \quad$ La Nauze, supra note 4 at 274.

64 Ibid. at 24.

65 Irving, supra note 1 at 70.

$60 \quad$ La Nauze, supra note 4 at 17.

67. Irving, supra note 1 at 66.

68 Ibid:; W.G. McMinn, A Constitutional History of Australia (Melbourne: Oxford University Press, 1979) at 102.

$69 \quad$ La Nauze, supra note 4 at 18. 
The result of the stress on state's rights was general support for a constitution drafted in the American style, with a single federal list. Most Commonwealth powers were formally concurrent, but, on account of federal legislative primacy (s. 109) they were really exclusive. The powers included external affairs and defence; currency, intellectual property, and bills of exchange; financial and trading corporations, bankruptcy and insolvency and cross-border trade; communications and infrastructure generally, though powers over railways were limited; marriage, divorce, and pensions; the arbitration of interstate industrial disputes.

Before examining what the courts would make of the $B N A$ and the Australian Constitution, it is important to consider what the framers had done.

\section{Sovereign Spheres: Public and Private}

The Australian and Canadian framers confronted a similar problem. They needed a legal framework that could reconcile the economic and idealistic motives for union with the hard, historic reality of colonial attachments and traditions of local autonomy. Both Constitutions would seek to solve the problem by dividing sovereign competence in two. But what principle informed the division? Noted above was the emphasis in Canada on central power and the preference in Australia for the states; but in criticizing the Canadian model, it was as if the Australian framers were standing near the Canadians but just on the opposite side of a line - and the question is the origins of the line. How does one know whether one is leaning towards regional or central rights?

The federation debates and discussions were full of the national-local distinction. Roughly, the federal governments were to deal with national issues, and the regional authorities local matters. But the terms were problematic. National problems were not problems of nationalism, but rather ones affecting the "whole country" as opposed to a part. However, that notion is difficult because many constitutional subjects have little to do with geography. Perhaps that is why the terms private and public also run through the debates and discussions. Indeed the $B N A$ uses the term "local or private" to describe the general provincial orbit. A rough division cuts the $B N A$ into the impersonal competencies of high economic management and the personal, familiar matters in 5. 92: family, charities, police, towns and cities, the administration of justice, and the maintenance of traditional equity between individuals. Similarly, Irving argues that the Australian Constitution was gendered, with the states relegated to the world of Victorian women. ${ }^{70}$ But the association of federal or national with the public interest, and the link between what is local and what is private - both seem inherent to federalism; James Madison made these connections in the Federalist (\#10)."

Of course public and private spheres shift. The impersonal, utilitarian world has advanced in fits and starts for a few hundred years. In the wake of the greatest of political revolutions, Burke famously complained that the age of personal honour was dead: "But

7 P. Johnson, A History of the American People (New York: HarperCollins, 1997). 
the age of chivalry is gone. That of sophisters, economists and calculators, has succeeded." ${ }^{\text {"2 }}$ Certainly in this century government regulation and more abstract notions of social, class or economic justice have gained ground on the traditional concepts of private justice, as embodied in contracts, torts, and property. As a result, federations have centralized, usually in periods of economic crisis where the emergency seemed to justify the invasion of private space by public interest. As well, growing national sentiment has tended to make some things that might have been public (that is, distant and impersonal) appear local because national feeling enlarges a sense of community. In any case, the two Constitutions reflect the growth of public space in the years of industrialization that separated the drafting of the $B N A$ and Australian Constitution. For example, industrial arbitration and pensions both made it on to the public list in the later Constitution.

Yet something crucial separated the Australian and Canadian Constitutions in terms of private and public law. The $B N A$ specifically gave the private law to the provinces; "private law" was more or less the meaning of "property and civil rights," and one cannot imagine the federal compact without it. ${ }^{73}$ This is because private law referred in part to a discrete legal tradition: namely, the Civil Law of Lower Canada. This specific, solid, and indeed codified manifestation of the private sphere of person-to-person relations had the advantage of being venerable while also appearing vulnerable; and one certainly has the sense that some courts enjoyed protecting it against the schemes of economists and calculators advanced under the Peace, Order, and Good Government ("POGG") and trade and commerce powers.

\section{SHIFTING SPHERES}

Scholars have probably argued less about the intentions of the Australian framers than the Canadian, and it is probably true that they have also agreed to a greater extent about the course of Australian judicial review. It has been a history of centralization. The growth of federal competence was quite rapid and thorough compared to the Canadian experience, though not nearly as speedy or complete as some labour governments would have liked. Historians usually explain the trend to strengthen the centre by referring to judicial ideology or the sociological nature of Australia, which became in the twentieth century more Australian. ${ }^{74}$ These arguments seem generally valid, but one has to be cautious with them. For instance, several referendums designed to centralize power have failed. ${ }^{75}$ As well, within the Constitution there was a principle that encouraged revision, the notion of public and private, which would naturally adjust to variegating conceptions of nationhood, economics, and justice. Finally, the decision to have one list of powers may actually have made state rights vulnerable.

E. Burke, Reflections on the Revolution in France, ed. by T.H.D. Mahoney (New York: BobbsMerrill, 1955) at 86.

73 Confederation Debates, supra note 12 at $41,45-46$.

74 For a comparative view of "national consolidation" in Canada and Australia, see B. Galligan, Politics of the High Court (New York: University of Queensland Press, 1987) at 22; B. Hodgins, "The Plans of Mice and Men" in B.W. Hodgins, D. Wright, W.H. Heick, eds., Federalism in Canada and Australia: the Early Years (Waterloo: Wilfred Laurier University Press, 1978) 3 at 6-8. McMinn, supra note 68 at 134. 
The history of judicial review in Australia is in two parts: before the famous Engineers case and after. ${ }^{76}$ In remarkable contrast with Canadian judgment, the Australians clearly expected that the division of powers would be policed by the courts, that a national court would be more sensitive to colonial-national needs than an imperial one, and that politicians should fill the bench. ${ }^{77}$ Indeed, the first High Court of Australia could not have been more political or sensitive, at least to constitutional history. Each judge had been a prominent federalist: Sir Samuel Griffith was the Queensland jurist who had written the 1891 Constitution, which was the Constitution in outline; Edmund Barton, who was noted above, had been one of Griffith's main collaborators and went to the bench from the Prime Minister's chair; R.E. O'Connor distinguished himself in the 1897-1898 redrafting sessions and later in the Federal Senate. ${ }^{78}$

This Court knew that the federal compact in Australia proceeded from two assumptions: First, the Constitution was strictly federal, with none of the breaches of the autonomous principle present in the $B N A$. Second, if the Constitution "favoured" a level of government, it was the states. ${ }^{79}$ Moreover, the Court understood that the framers had believed that the best way to capture the compact was the American technique: a list of federal powers with the residuary to the states. The question, then, was what technique would the courts use to protect and elaborate this bargain? The High Court of Griffith and Barton had to be, in fact, quite creative or "active" in fleshing out the Constitution, and one has to wonder if the two men had realized, when they advocated the American model, the degree to which they had made the prerogatives of the states dependent upon the vagaries and politics of judicial review.

Three anchors of principle were to keep the words of the Constitution moored to the intent of the framers: First, the Constitution was federal, which required autonomy and implied balance. Second, neither the federal nor the state governments had authority to interfere with each other. Third, the use and extent of designated federal powers had to conform to the residuary competence. ${ }^{80}$

A federal constitution cannot remain federal without the first principle of interpretation. The second concept, as a practical expression of the first, is also necessary. However, it can make a federal system static if interpreted too expansively. "Implied immunities," which descended from a precedent of no less renown than the Marshall Court's judgment in $M^{\prime}$ Culloch v. Maryland, ${ }^{81}$ was another example of the influence of American law in Australia; and it was not difficult to accuse Barton and Griffith of being slavish rather than selective in their choice of American shoots to graft into Australian law. Still, even a severe employment of the rule would apply to both levels of government, so in general they had as much to gain as to lose by it. In 1904 the High Court held that states could Engineers].

Galligan, supra note 74 at $48-56,77$.

Ibid. at 79.

La Nauze, supra note 4 at 18.

Zines, supra note 60 at 105 .

4 U.S. (Wheat.) 316 (Sup. Ct. 1819). 
not tax federal civil servants on their salaries. ${ }^{82}$ The states had a victory two years later in Railway Servants; their railways did not fall under the jurisdiction of the Commonwealth Arbitration Court. ${ }^{83}$ The issue of whether the states had to pay duties on imports led quite literally to a federal-state skirmish, the "Battle of Darling Harbour." The Griffith Court introduced some flexibility but no useful principle when it decided that the levies applied. ${ }^{84}$

One can certainly argue that implied immunities was a conservative doctrine, both jurisprudentially and politically; for it tended to box in governments. But it was the third anchor of the federal equilibrium that raised the ire of reformers, for it limited federal power and necessarily involved great discretionary judgment. Thus in King v. Barger ${ }^{\text {s5 }}$ the Court ruled that the federal government could not use taxation sticks and carrots to regulate conditions of employment; this subject was not in the Constitution, so it belonged to the states. Similarly, in Huddart, Parker v. Moorehead ${ }^{86}$ the Court found no authority in the federal power over "foreign corporations, and trading and financial corporations" to uphold a monopoly law, which might interfere with interstate business activities, a field the Constitution had set aside for the states. It is of course difficult for regional governments to run an anticombines scheme, and, in the fall out of Huddart, a labour organ wondered if "it was not time we resolved to wipe out all restrictions on Commonwealth power." ${ }^{37}$ Public space was pressing against private.

Something of a federalist revolution did occur, though the courts have been working out the details for eighty years. Indeed, little of the Griffith Court's architecture still exits, and the result in most of the above cases has been reversed. ${ }^{88}$ The upheaval had two immediate causes. The profound cause was World War I. Historians often cite two features of the War: that it shaped the character of the century and that it was "total." The prosecution of war may be the most public of acts, and this war reached deep into civil society, pulling private forces into the public domain. In some countries the tide of public space never receded: "the private life is dead" several characters state in Dr Zhivago. But even non-totalitarian countries grew comfortable with the new collective spirit and the emergency imperative transferred to various social "struggles," the "war on poverty" and "campaigns" to increase productivity or health. During the Great War Australian government approached a unitary state. The High Court legitimized Commonwealth price fixing in Farey v. Burvett ${ }^{89}$ on basis that the defence competence covered any law connected to military victory in an actual war. Food, Issac J. commented, had become a

Deakin v. Webb (1904), 1 C.L.R. 585.

Federated Amalgamated Government Railway and Tramway Service Association v. New South Wales Railway Traffic Employes Association (1906), 4 C.L.R. 488 [hereinafter Railway Servants].

New South Wales (A.G.) v. Collector of Customs for New South Wales (1908), 5 C.L.R. 818 [hereinafter Steel Rails Case].

(1908), 6 C.L.R. 41.

(1909), 8 C.L.R. 330 [hereinafter Huddart].

Galligan, supra note 74 at 87.

McMinn, supra note 68 at 132 .

(1916), 21 C.L.R. 433. 
weapon and its price was open to federal regulation because of the "transcendent" character of the war. ${ }^{90}$

Just as few governments retreated within their pre-1914 capacities, so the Commonwealth never fully withdrew from state fields. The High Court did not order a "demobilization" because its personnel had changed. In 1906 Henry Higgins and Isaac Isaacs, who both believed in liberal reform from the centre, were appointed to the Court in the expectation that they would weigh the scales in favour of the Commonwealth; ${ }^{91}$ and by 1920 all three of the original justices were off the bench. In that year, the High Court considered whether a number of enterprises "nationalized" by western Australia were immune from the Arbitration Court. ${ }^{22}$ Engineers overturned Railway Servants by expressly abolishing implied immunities and it rendered uncertain the status of the implied prohibition doctrine. The practical ratio of the case was that courts should give full meaning to the enumerated powers without concern for federal implications.

The result of this ruling was basic. Before Engineers, federal power existed like oil in water, a visible liquid defined by the invisible surrounding pool of state prerogatives; after Engineers, with the pool removed, the oil simply spread in the vacuum. Although Isaac J., who wrote the Engineers judgment, stated that the Court was merely interested in removing extraconstitutional principles from judicial review, it is fairly clear that at least he and Higgins approved of the expansion of federal power since the War and wanted to further it. They continued to reinforce the centre, so that, for instance, the banking power expanded with that new doctrine of public management, Keynesianism; ${ }^{93}$ and the centripetal tendency of the Court has not been checked. The question, then, is why World War I did not have the same effect on Canadian as Australian law?

The Privy Council, which heard appeals on the Constitution until 1949, had been if anything, more predisposed to regional government than Griffith and Barton. But, as in Australia, the War did (temporally) centralize Canada and no doubt it also helped to change attitudes towards private and publics realms, as did the general rise of socialism and interventionist economics. When the next national emergency, the Great Depression, struck, the response of the ruling Conservatives was to expand the role of the federal government in economic and social welfare fields. This initiative ran up against the concern of the Privy Council about provincial autonomy, ${ }^{94}$ and from this time dates a vast polemic literature, the central idea of which is that the Privy Council's interpretation of the Constitution denied Canada the chance to deal with its public predicaments.

Critics and scholars of the Privy Council largely agree that the tribunal's rendering of the Constitution was not in accord with the spirit and perhaps even letter of the $B N A .{ }^{95}$

Ibid. at 451, 454.

Galligan, supra note 74 at 83.

Engineers, supra note 76.

Ibid. at $164 \mathrm{ff}$.

Canada (A.G.) v. Ontario (A.G.), [1937] A.C. 327 [hereinafter Labour Conventions Case].

An exception is the work of G.P. Browne, who argues that the Privy Council dispassionately and correctly interpreted the BNA. G.P. Browne, The Judicial Committee and the British North America Act (Toronto: University of Toronto Press, 1967). 
In order to explain the discrepancy, commentators have conjured an extraordinary variety of motivational theories: ideological opposition to centralized reform; sensitivity to Canadian regionalism and public opinion; the presence of Scottish judges on the Board; Lord Haldane's Hegelianism; sympathy for Irish Home Rule; imperial aversion to colonial nationalism; even a bureaucratic survival instinct, which sought to maintain the tribunal's jurisdiction by keeping the provinces happy ${ }^{96}$ It is not possible to review each of these ideas, and some of them may have merit, but a few points should be emphasized. First, as noted above, the Canadian federal compact was not necessarily what Macdonald said it was when he was in his most centralist mood. Second, even if one party alone had written the Constitution, judicial review might not exactly mirror that person's intentions because not everything is legally possible. For instance, there are some senses in which it is not feasible to balance federal and unitary elements - a constitution is either one or the other according to principle. Finally, in comparison with the Australian Constitution, the technical structure of the Canadian Constitution serves to protect provincial authority, and the private element is more firmly imbedded.

The Privy Council's simplest decision about the $B N A$ was to treat it as a federal constitution, which meant the two levels of government were autonomous within their jurisdiction, and the Board would presume terms to say so. ${ }^{97}$ If anyone in the British North America of 1867 had wanted an administrative union, where the federal government could assume provincial powers, they should not have sold the Constitution as federal. Second, the Board defined the two lists of power by reference to each other. Mutual modification did not insure a particular result and it was not necessarily harmful to federal authority. Yet the ratio of the case in which it originated, Citizens Insurance v. Parsons, ${ }^{98}$ still seems eccentric, since the Privy Council reduced the federal authority over "trade and commerce" to a power over interprovincial trade, which was an express limitation in the American and (eventually) Australian Constitutions. However, the Supreme Court, while being more flexible, has not overturned Parsons because it does seem that the federal prerogatives to legislate on trade and commerce have to accommodate the general provincial jurisdiction over contract law. We see here that a crucial assumption of the framers of both the Australian and Canadian Constitutions was incorrect: a provincial or state list of powers may be better protection than a general residuary because specific rights are tangible and depend less on judicial implications and presumptions. $^{99}$

Finally, because of mutual modification, the Privy Council had to define the broad federal capacities against the comprehensive provincial claims over property and civil rights and local matters. On several occasions, the Board confronted a public policy or economic statutory scheme that might infringe on areas of traditional law, and it usually

For a review of some of these theories, see A.C. Caims, "The Judicial Committee and its Critics" in G. Stevenson, ed., Federalism in Canada (Toronto: McClelland \& Stewart, 1989) 81.

Hodge v. Queen (1883), 9 App. Cas. 117 at 132; Liquidators of Maritime Bank of Canada v. Receiver General of New Brunswick, [1892] A.C 437 at 441.

(1881), 7 App. Cas. 96 [hereinafter Parsons].

For a comparison between mutual modification and implied prohibitions, see Zines, supra note 60 at 105; C. Gilbert, Australian and Canadian Federalism 1867-1984 (Melbourne: Melbourne University Press, 1986). 
chose to preserve the latter. In Parsons the Board deduced the meaning of "property and civil rights" as private law by examining s. 94, which provides for potential uniform law among the original three common law provinces. The Privy Council grounded its judgment on the need to protect the common and civil law of contract, noting that a generous reading of trade and commerce would allow the federal government to do what it could not under s. 94: that is, amalgamate the law of Quebec with that of the common law provinces. ${ }^{100}$ Respect for French-Canadian law on the Privy Council bench is not startling. Lord Haldane, with his Hegelian sense of diversity and synthesis, noted that the distinctiveness of the Privy Council rested in the fact that it ruled on private law issues in multitraditions, from the Hindu law of India to the Dutch law of South Africa. ${ }^{101}$

It was not uncommon for the Board to refer to the $B N A$ as a pact, treaty or contract and indeed it sometimes borrowed from the language of contract and equity. For instance, Lord Sankey, who gave judgment in some of the federal victories in London, applied the doctrine of reliance to the federal bargain; minorities, he noted, had entered Confederation on certain terms and therefore had a right to expect that courts would enforce the original arrangement. ${ }^{102}$ However, it is less than clear that many members of the Privy Council were sympathetic to minorities as such, given that federal power (like disallowance) benefited provincial minorities while limiting the autonomy of national ones.

Nor was there any mention that linguistic diversity in general should affect the division of powers. Rather, the strong guarantee of autonomy in matters of private law, given definition and political significance by the presence in Canada of Lower Canadian civil law, compelled respect from the Court. In the highly controversial Labour Convention Case, where he ruled ultra vires the Bennett Government's bill to implement a labour standards treaty, Lord Atkin stated:

If the position of Lower Canada, now Quebec, alone were considered, the existence of her separate jurisprudence as to both property and civil rights might be said to depend upon loyal adherence to her constitutional right to the exclusive competence of her own Legislature in these matters. ... [A treaty implementation power] would appear to undermine constitutional safeguards of Provincial constitutional autonomy. ${ }^{\text {103 }}$

Thus the federal compact, by preserving the private law traditions of French and English Canada, had in part shielded the country from the expansion of public law. One wonders what Lord Durham would have thought of a Canada where a national commitment to the preservation of a distinct French institution had insulated both communities against modernizing trends. 


\section{CONCLuSion}

Canadian and Australian union was part of the rise of new continental countries in the nineteenth century. Federal borders pursued, to some degree, the new economies of scale, which increased as relative economic distance shrank. The countries came together as federations because the division of sovereignty made the process of integration easier. The "expansionists," who were enticed by economic opportunity or lured toward wide horizons or who wanted to build national political architecture, took from federation a larger canvas on which to paint. The "localists," who wanted to continue in the private worlds they inhabited before union, lived on within local realities that federation left largely undisturbed. That was federalism's appeal, the simultaneous promise of public expansion and private autonomy.

With hindsight one can speculate that the federal adventure might have been easier still had a few things been different or better understood. The Canadian compact was always federal, because French and Maritime Canada would never have agreed to less; but one can legitimately wonder if Macdonald understood that the essence of federalism is not vague "balance." Rather, it is guaranteed mutual autonomy within a political union. Similarly, the neglect of the autonomy principle in the Australian High Court suggests that the country will become less and less what the lawmakers intended, without anyone voting for a change. This result may be justifiable on nationalist or economic grounds, but it is hardly good for the rule of law. Still, the federal story, in which courts gained such extraordinary power to create and interpret new law of the most meaningful kind, suggests, mundanely, that judges are motivated by all sorts of factors, among them economic ideology and legal principle. Other lessons are mixed: it is difficult to image, for instance, how the Canadian and Australian framers could have realized, when considering whether to have one or two lists of powers, that their expectations were wrong. The limit of legislative foresight is an arresting aspect of the federal story, and it does invoke Robert Burn's words about the best laid of plans.

Still, it may be wrong then to strike too ironic a tone. The Canadian and Australian Constitutions were not just products of la belle époque, but justify its optimism. Based on consensus, they were not born of bloodshed, and they did provide a framework in which people could profitably share economic and cultural space. As well, unlike most written constitutions, they have endured. Neither country is perhaps what the framers specifically intended, and both dissatisfied centralists and discontented "state's rights" advocates may have reason to complain of contractual breach. But expansion and autonomy have coincided; continental federalism has kept something of its original promise, justified something of the framers' fides. 